\title{
Territory and territoriality: retrospect and prospect
}

\section{David Storey}

\section{Introduction}

The word 'territory' is commonly used to refer to an area of land claimed by a state, or to a 'homeland' associated with, or claimed by, a national grouping seeking self-determination. The word tends quite often to conjure up images of highly contested political spaces such as Kashmir, Nagorno-Karabakh or Northern Ireland. Although territory might be seen as a core geographical concept, it is one that has tended to be taken for granted and treated in a somewhat descriptive sense until comparatively recently. Territoriality is normally seen as the actions or behaviours used to control or exert power over a geographically designated space. The pioneering work of Robert Sack (1986) drew attention to territoriality as a spatial expression of power. More recently, ideas of territory and territoriality have been interrogated in more depth (Delaney 2005; Storey 2012), a heightened attention further reflected in the launch of the journal Territory, Politics, Governance in 2013 and in edited volumes drawing together recent scholarship (Paasi et al. 2018).

Crude deterministic perspectives suggest that humans are imbued with a territorial imperative that is seen as a natural and unchanging phenomenon. The need for space is interpreted as a characteristic innate to all species manifested through an impulse to defend their territory against others seeking to 'invade' it (Ardrey 1967). In a related vein, the geographer Friedrich Ratzel developed organic theories of state formation in the late 19th century arguing that state expansion was a necessary means of ensuring a country's survival. Drawing parallels with evolutionary theory, he suggested that states needed to adopt 'survival of the fittest' strategies in order to retain power, an argument serving as a convenient justification for aggressive territorial defence and the acquisition of colonies (Bassin 1987). 
While it is tempting to relate territoriality to some inbuilt feature of human beings, more nuanced perspectives suggest that much of our territorial behaviour is a consequence of our broader socio-political conditioning and should therefore be analysed within its social and political (rather than biological or genetic) context, where territories are seen to be socially produced and territorial strategies can be viewed as mechanisms to achieve particular ends. Rather than adopting simplistic deterministic explanations, it seems reasonable to assume that we are subject to complex sets of influences within our broader environment. Instead of viewing them as natural entities, territories might be seen to reflect specific ways of thinking about geographic space; they are products of social practices and processes that link space and society (Delaney 2009; Elden 2013a). It follows that territories and territorial strategies are not just visible manifestations of political processes, they are also symbolic. Political power is conveyed, both materially and symbolically, through territorial occupation and the creation and securing of borders. Territory is also intimately bound up with identity and can be used to instil and reproduce a sense of loyalty and affiliation, being central to ideas of the nation. However, territories can also be seen to exist (with various degrees of control, contestation and forms of bordering practice) across a range of spatial scales, in many diverse contexts and through various forms of what Sidaway (2007) has referred to as spatial enclaving. This can be seen through such things as the growing phenomenon of gated communities, patrolled commercial and leisure spaces, and other examples of the partial privatization of formerly public space (Bagaeen and Uduku 2010; Paasche et al. 2014). Most people are regularly confronted with signs such as 'Authorized Personnel Only', 'No Trespassing', 'Prohibido el Paso', and so on. Such regular warnings and admonishments are a reflection of attempts to impose forms of power, via sets of rules and regulations, through the control of portions of geographic space. Space is claimed, boundaries are produced and patrolled, and territorial strategies are deployed across a range of spatial scales. Of course, such strategies are not always successful, and claims on space are often contested, while boundaries may be regularly transgressed.

Following a discussion of ideas of territory and territoriality, this chapter considers both territorial practices and the significance of territory in a range of contexts. Following this, there is a focus on the territorial state before dealing with a key element of territorial practice: borders. The subsequent section focuses on the significance of territory in the sustaining of ideas of the nation. Finally, the chapter turns to forms of territory and territorial practice below and beyond the level of the state. The chapter thus sets the scene for the more specific contributions that follow. 


\section{The concept of territory and territorial strategies}

An early and highly significant contribution to the investigation of ideas of territory is that by Jean Gottmann (1973). He argued that territory confers security through the control of defensible space while also providing a range of opportunities through facilitating the economic organization of that space. This emphasis on security and opportunity points to a political and economic basis for territorial formations which makes for a more efficient means of political organization than systems of overlapping jurisdictions. Swiss geographer Claude Raffestin (2012) views territories as emerging out of social interactions. For him, territoriality might be viewed as a process produced by the various relationships between individuals, groups and their wider social environment. More recently, Stuart Elden (2010, p. 803) has pointed to the failure to further explore the idea of territory, suggesting that it has long been taken for granted so that 'strategies and processes toward territory ... conceptually presuppose the object that they practically produce'. In unpicking the term, Elden suggests that territories themselves, and their boundaries, reflect a distinctive mode of social and spatial organization linked to particular ways of thinking about geographic space. These are intimately connected to ideas and practices of power and control. Elden's (2013a) pioneering work traces the emergence of the concept of territory, and he argues that our contemporary ideas of it emerged alongside developments in cartography and geometry; it is something that can be calculated, mapped and controlled. Territory might be seen as a rationalizing of space which has emerged through a series of social and political practices; and territoriality, in allowing classification and differentiation, is an outcome of the ways in which space is imagined. In effect, territories are politicized space; mapped and claimed, ordered and bordered, measured and demarcated. For Elden, territory is something 'shaped by, and a shaper of, continual processes of transformation, regulation and governance' (Elden 2013b, p. 17).

It is clear that maps and cartographic techniques have been intimately bound up with the solidification and legitimization of territorial units. Mapping of territory itself functions so as to enhance power, sending out messages signifying control over portions of geographic space (Harley 1988). Advances in cartography altered the ways in which space was considered, thereby facilitating attempts to apportion and control it. The military and political underpinnings of cartographic developments, and the consequent role of mapping, in both practical and symbolic terms, in the creation of colonial territory was a key element in the imposition and maintenance of control (Smyth 2006; Hewitt 2010). Maps had the very practical use of facilitating the extraction of 
resources, as well as the symbolic function of depicting power over space. The cartographic depiction of space became a signifier of sovereignty, giving it visible form. Territory was both a political and an economic resource, but one that needed to be mapped precisely.

Robert Sack's key work in the 1980s focused on territoriality as a geographic and political strategy through which individuals or groups endeavour to 'affect, influence, or control people, phenomena, and relationships, by delimiting and asserting control over a geographic area' (Sack 1986, p. 19). He emphasizes the instrumental nature of territoriality, and draws attention to the means through which territorial strategies may be used to achieve particular ends so that control of space can be used to assert or to maintain power, or, importantly, to resist the power of others. What this means is that territoriality is deeply embedded in social relations, so that territories, far from being natural entities, are the result of social practices and processes and are produced under particular conditions in order to serve specific ends (Delaney 2005).

These perspectives are important not only in emphasizing the political context of territorial behaviour but also in highlighting how territoriality as a strategy operates at all spatial scales, from the geopolitical machinations of global superpowers down to the allocation of micro-spaces in the home and the workplace. Sack also draws attention to the significance of territoriality in facilitating classification, communication and enforcement. Territoriality involves a classification by geographic area through which space is seen to be apportioned between states or between individuals. In this way a room, or an office, or a workstation becomes 'my' territory and others are discouraged from encroaching, except by invitation or prior agreement. Sack also argues that territoriality is easy to communicate via the use of boundaries indicating territorial control and, hence, power over prescribed space (and of those within it). In this way there is a distinct separation between those who are 'inside' and those who are 'outside', thereby conveying clear messages about power and control. In this way territory, and associated border construction, in classifying space and communicating power, acts as a device for the enforcement of authority. Clearly, this has potentially important implications in constraining, restricting or limiting people's mobility.

Another tendency of territoriality identified by Sack is that it functions as a means through which power is reified. Through the visibility of land, power can be 'seen' in a way which suggests that 'territory appears as the agent doing the controlling' (Sack 1986, p. 33). This reification is most obviously apparent in the deployment of the term 'the law of the land', whereby power appears to reside in the territory itself. Attention is thereby diverted away from the 
power relationships, ideologies and processes underpinning the maintenance of territories and their boundaries. In this way, 'territory does much of our thinking for us and closes off or obscures questions of power and meaning, ideology and legitimacy, authority and obligation' (Delaney 2005, p. 18). Underlying assumptions and processes are thus effectively hidden from view. This interpretation of territorial behaviour emphasizes the political functions of territoriality so that it can be seen as 'a primary geographic expression of social power' (Sack 1986, p. 5).

Once created, territories can become the spatial containers in which people are socialized through various social practices and discourses. Paasi (2008) suggests that the material and the symbolic are combined through territory so that land is controlled while the symbolism associated with it feeds into people's social identity. In this way, the spatial is not simply a product of the social; rather, the two are intimately bound together. Painter (2010) argues that territories result from social practices and are solidified through an accumulation of seemingly banal administrative procedures. Such things as the collection and production of regional statistics and the devising of regional economic strategies give material form to territorial configurations and confer a sense of contiguity and coherence. Ultimately, territory is intimately bound up with the discourses and practices of power and control which, in turn, serve to reproduce territory.

\section{The territorial state}

Territory is most obviously thought of in the context of the state system, serving as the functional space within which the state operates and wields power, and it might be seen as a key and necessary feature of the state, with borders serving as the dividing lines where state control both begins and ends. However, while the territorial state is at the centre of the global political system, we need to be careful not to fall into what Agnew (1994) long ago termed the territorial trap, whereby the state is 'naturalized'. Agnew argues that states are imagined as fixed sovereign entities with power over their territory, in turn suggesting a clear distinction between 'domestic' and 'foreign', whereby states are characterized as territorial containers of economy and society. However, Brenner and Elden (2009) argue that territory, rather than simply being a feature of the state, both facilitates and emerges from state action. The demarcation of territories and the bounding of space obviously bring with them issues of exclusion and control. Territories, and their boundaries, are frequently the centre of often violent disputes, and the areal extent of particular territories, or 
even their very right to exist, may be regularly called into question. Rather than being fixed immutable entities, human territories and their boundaries are subject to periodic or continuous contestation, modification, transformation and destruction through the shifting spatialities of power (Paasi 2009).

Maier (2016) sees territory as a way in which space is both imagined and organized. As states evolved, he argues there was a concern both with establishing borders and with organizing space within those borders. Cadastral mappings of property allowed for the enclosure and privatization of geographic space, in turn facilitating the control and extraction of resources. Alongside these cartographic developments, other technologies played a key role, with industrialization and advances in communications being crucial. Railways became what Maier terms 'sinews of the nation-state' as they permeated, and hence drew together, the national space. As the state solidified as a centralized political unit, and as technological advances continued, attention turned towards territorial accumulation through the acquisition of colonies.

Although much discussed, sovereignty is often seen in overly simplistic ways as the right of the state to rule over its territory and those within that geographic space. However, sovereignty has always been something of an abstract and idealized notion, and the sovereign power of an individual state is continually challenged, contested and modified. Processes associated with globalization (or linked together under that broad umbrella term) have been seen by many as signalling a diminishing sovereignty for the territorial state. In some narratives, borders have become depicted as increasingly porous in a world of transnational flows of people, goods, finance and ideas. However, despite predictions of the demise of the state and the supposed advent of a borderless world, the reality appears rather more complex. While a neoliberal economic orthodoxy centred on transglobal economic flows seems to point towards the irrelevancy of borders, it simultaneously utilizes and reconfigures them in attempts to increase the returns to capital. In addition, there is the apparent paradox that while capital flows relatively freely across international frontiers, many people (depending on who they are, where they are from, and where they are trying to go) are faced with the intimidating paraphernalia of the state manifested at border crossing points.

The rise of right-wing populism and anti-immigrant sentiment in the early 21 st century appears to reflect a reassertion of the state and ideas of territorial sovereignty. The 2016 United Kingdom (UK) vote to leave the European Union (EU) suggests a return to harder borders, a situation further epitomized by the (re-)erection and solidification of borders throughout Central Europe designed to impede migration into the EU. United States (US) President 
Donald Trump's intention to construct a border wall between the US and Mexico is a stark example of the rhetoric surrounding borders and their control, though that rhetoric omits acknowledgement that sections of wall and fencing already exist along lengthy stretches of that frontier. In this sense, recent political developments seem to reflect an intensification of bordering practices rather than being a new departure. In any event, discontent over globalizing processes has contributed to an inward-looking parochialism that seeks to shut out alien others.

Far from disappearing, territory is continually being reconfigured and spatial political relations are constantly being reshaped in ways suggestive of reterritorialization, rather than deterritorialization (Elden 2010). Power is unequally distributed, and some political-territorial formations exert significantly more than others. Some states display a willingness and ability to exert power well beyond their formal territorial boundaries, while others (sometimes labelled 'failed' or 'rogue' states) become arenas for external intervention. The linkages between state sovereignty and territorial control are far from straightforward and lead to a consideration of effective sovereignty wielded by both states and quasi-state actors and deployed across a range of territorial contexts (Elden 2009; McConnell 2010).

Sassen (2013) writes of the growing disjuncture between territory and state sovereignty in a heavily interconnected world. She sees territory as a capability that has a wider array of formats than simply the state. She suggests that we need to think in terms of complex jurisdictions that cross borders, creating holes in state sovereignty, or what might be seen as a weakening of territoriality when understood as legal control of geographic space. The creation and maintenance of military bases in other countries and the economic and political pressures exerted, both directly and indirectly, by major powers further highlights the contingent nature of state sovereignty, through which some states might be said to possess the capacity to be considerably more sovereign than others through the exercise of military or economic muscle. US drone and other attacks in Pakistan, together with the presence of naval forces in the Persian Gulf and elsewhere, represent asymmetrical interpretations of sovereignty whereby more powerful actors presume to act on a considerably more global stage than that permitted to others whose sovereignty may conversely be highly constrained. US geo-economic strategy is pursued via a complex array of military bases, installations and agreements with a host of other countries across the globe, in what has been referred to as a form of 'leasehold empire' (Sandars 2000). This facilitates control over access to resources in a way in which regulation of extraterritorial space is taken to be the norm for the purposes of US national political, strategic and economic interests. Regions such 
as the Middle East are scripted in particular ways with an underlying rationale that is more about territorial access to resources rather than formalized territorial control (Morrissey 2017). In a similar vein, it might be suggested that China's overseas investment in various parts of the world, notably in a number of African countries, can be seen as a geo-economic strategy pursued territorially (Carmody 2016). Alongside this, the activities of major transnational corporations, with their highly complex geographies of production, distribution and marketing, serve to deepen the array of actors that wield forms of power within and across state borders.

Our state-centred view of the world means that there is a risk of seeing territory as a mere canvas on which political processes play out (Kadercan 2015). However, the state system is a political and geographic construct that displays considerable dynamism. In recent decades the number of states has risen dramatically, consequent on state collapse (many associated with the fall of communism in the early 1990s) and secessionist nationalism. Clearly, secessionist ideologies (Basque, Kurdish or Scottish nationalism, for example) are premised on the construction of a territory, politically detached from the state(s) to which it currently belongs. States themselves may respond to these pressures in ways that are coercive or conciliatory (or a mixture of both) in order either to suppress or to placate; while regional identities rub up against broader national ones, sometimes reasonably harmoniously, sometimes less so (Terlouw 2018). Elsewhere, groups such as Islamic State in Iraq and Syria and Boko Haram in Nigeria have utilized the control of space in the pursuit of ideological objectives. The emergence of quasi-states such as South Ossetia (officially part of Georgia) and Transnistria (formally belonging to Moldova), where sovereignty is proclaimed though not internationally recognized, reflect a means of territorial construction through opting out of larger spatial-political entities (Blakkisrud and Kolstø 2011; O'Loughlin et al. 2011) (Figure 1.1). While such territories may have internal administrative control, they lack wider legitimacy, and their continued existence is usually dependent on an external patron state (Bakke et al. 2018). Issues of territorial integrity also emerge regarding sets of island states, and there are a range of highly ambiguous entities such as Diego Garcia, officially a British dominion but leased to the USA, and with its indigenous population displaced elsewhere. The ambiguities associated with such territories are further explored in Chapter 5 of this book by Nichola Harmer.

Ultimately, territorial sovereignty is relative, contingent and never complete. It may be more useful to think in terms of effective sovereignty wielded by both states and quasi-state actors, and deployed across a range of territorial contexts where sovereign power does not automatically stop at the border but oper- 


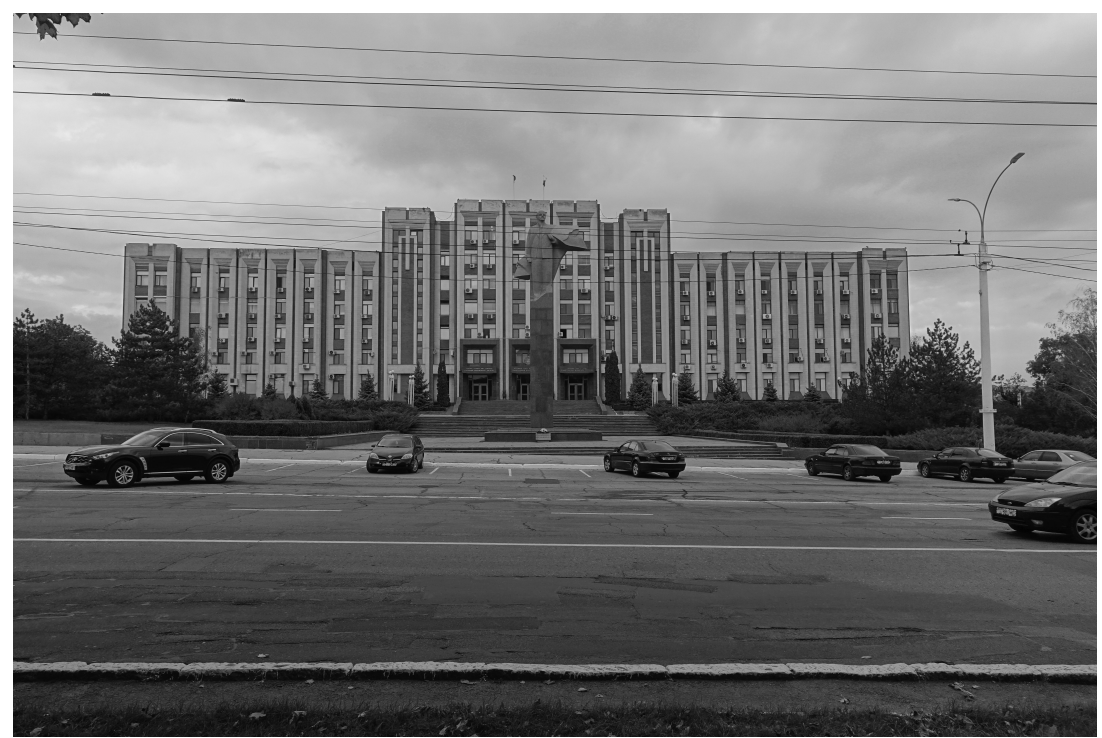

Source: Author.

Figure 1.1 Parliament building in Tiraspol, capital of the breakaway Transnistria Republic

ates through a number of complex interstices (Elden 2009; McConnell 2010; Kadercan 2015). The effective sovereignty of many states is reduced through various processes and global flows, and states operate alongside a widening range of non-state actors who might be seen to exert power across networks rather than over rigidly bordered territory. This, however, is not necessarily a completely new departure, as Agnew (2009) reminds us that states have never been hermetically sealed as sovereign spaces and have always been fragmented, overlapping and multiscalar, a phenomenon exacerbated (but not created) through various strands of globalization. More broadly, some have begun to suggest that jurisdiction and sovereignty are not inextricably dependent on territory and boundaries, and the relationship between territory, property, assets and the law is becoming increasingly complex (Blomley 2016). As well as the jurisdictions of such bodies as the International Criminal Court, we also have the phenomenon of cities such as London becoming key arenas for the settlement of legal cases involving non-domiciled businesspeople. Nevertheless, as Paasi (2009) suggests, in spite of these increasingly complex and multifaceted interactions and networks, the state still acts as an organizer and regulator of territorial spaces, even if those spaces are becoming increasingly porous. Chapters 2 and 3 in this book by Alexander B. Murphy and John Agnew, 
respectively, further develop these complex connections between territory, power and sovereignty, while Amy Trauger's focus on food in Chapter 7 raises further questions about the nature of sovereignty and the contested terrain of state power.

\section{Borders and bordering}

As ideas of territory evolved, so the importance of demarcation grew. Maier (2016) suggests that early expanding empires accumulated territory, sometimes violently, sometimes peacefully through the incorporation of land, and the frontier was seen as a zone of fluidity, representing a temporary boundary inviting expansion beyond it. The rise of the bounded state as a political unit necessitated a concern with the drawing and redrawing of political borders and the formalization of territorial arrangements. Borders have become places where the distinction between 'our' territory and that of others is made clear, with the paraphernalia of the state very evident through flags flying at crossing points, passport checks and police controls. Notwithstanding ideas of 'natural' borders, it is patently obvious that borders, whether utilizing naturally occurring features such as rivers or mountain ranges, are intrinsically artificial. States are human creations and, as a consequence of political decisions, some rivers become borders (or cease to be borders) while others do not. Ethnic or national identities are not fixed or unproblematic and it follows that the territorial divisions separating them are not 'natural' (Fall 2010).

Borders are constantly subject to change resulting from disputes over territory. These disagreements may relate to the precise location of the border or they may centre on the very existence of a border in the first place. The relative significance of certain borders changes over time. The Austria-Czechoslovakia border was once of huge political import, separating an EU member state from one in the communist eastern bloc. Now Austria's border with Slovakia (which split from the Czech Republic after the collapse of communism) is comparatively insignificant, with relatively free movement between two EU members (Figure 1.2). The political conflict in Ireland revolves around the existence of the border between the Republic and the North. For Irish republicans, who wish to see a unified Ireland, the border is at the heart of the conflict, viewed as an imposed and artificial boundary whose removal is essential. While there has been relative peace since the late 1990s when the border became innocuous in most practical terms, Brexit (the exit of the UK from the EU) means that the Irish border seems likely to assume huge additional significance as it is likely 
to become a 'harder' border separating the UK from another EU member state (Figure 1.3).

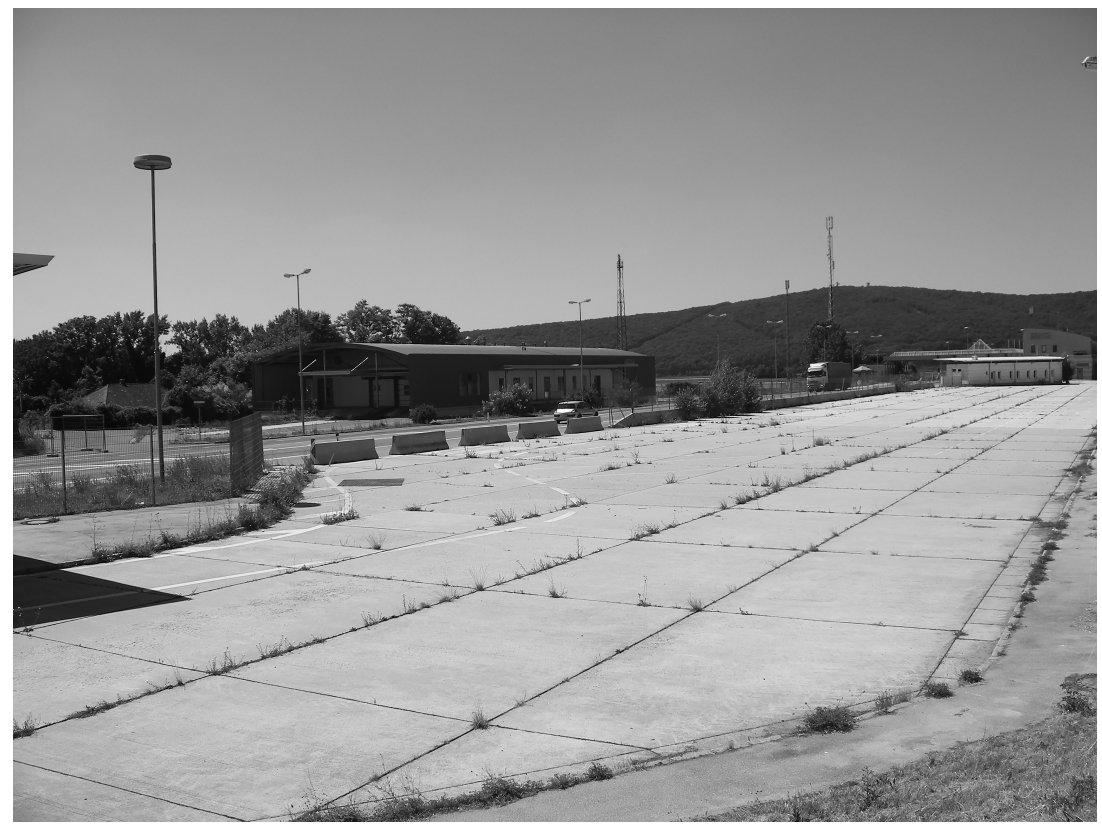

Source: Author.

Figure 1.2 Unpatrolled border crossing between Slovakia and Austria near Bratislava

Borders are not just lines dividing territory; they are social and discursive constructs with important ramifications not just politically, but also in people's everyday lives. In many respects, the imposition of a physical border can result in the emergence of a partitionist mentality contributing to the essentializing of national identity and the accentuation of linguistic and cultural divisions. The evolution of a sense of difference between 'east' and 'west' Germans might be seen as a consequence of that country's political division between 1945 and 1991. Similarly, other national borders which served as Cold War boundaries had profound impacts on those living in close proximity to them (Meinhof 2002). Political decisions taken in remote political centres can have dramatic effects on people who find their lives disrupted by shifting borders, as the partitioning of space also partitions the lives of many. The demise of the Soviet Union had serious repercussions for more nomadic groups who 


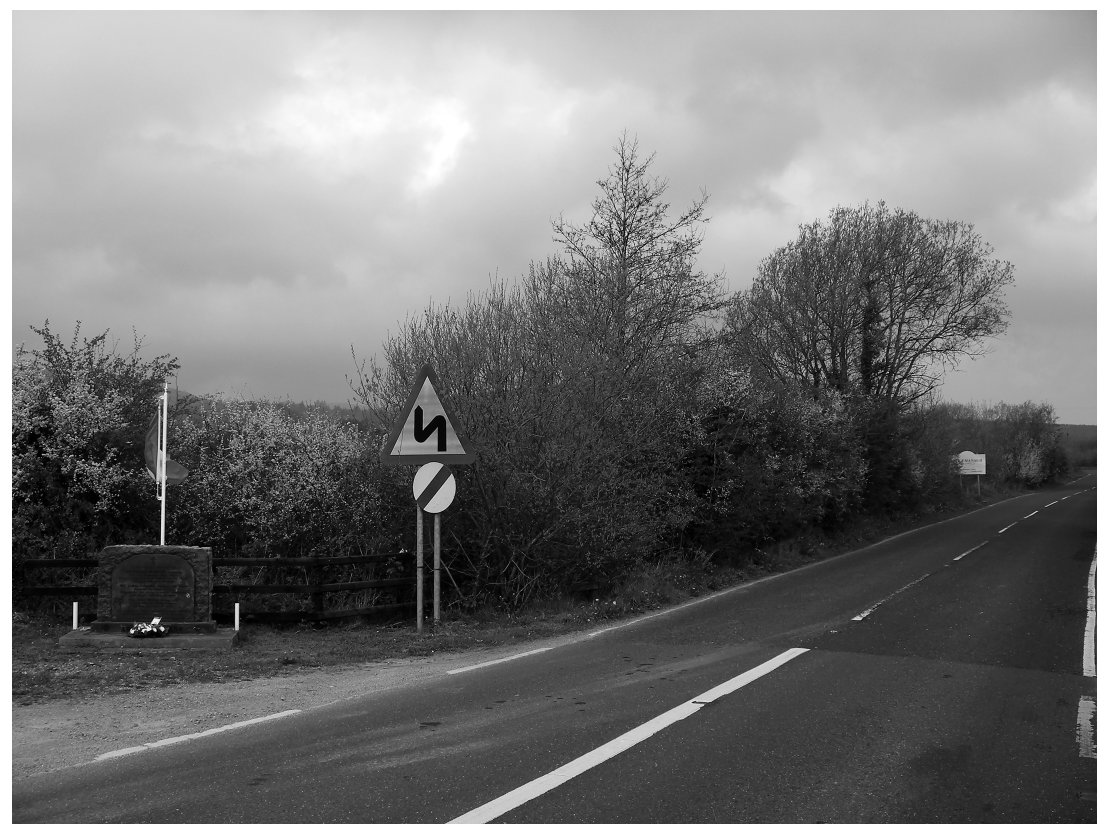

Source: Author.

Figure 1.3 Border between Republic of Ireland and Northern Ireland

found their territory ruptured by international boundaries. Any redrawing of borders will of necessity result in some finding themselves on what they feel to be the 'wrong side' or having their mobility circumscribed by its presence. In a myriad of ways, borders become elements within people's everyday lives and shape their day-to-day being (Leary 2016; Nash et al. 2016). For people in contested zones, such as the Ferghana Valley in central Asia where Uzbekistan, Kyrgyzstan and Tajikistan intertwine, state efforts at nation-building and associated territorial demarcation have very real impacts (Megoran 2017). Border areas may assume a very central importance for newly emerging states such as South Sudan where central government needs to be seen to assert control and, in doing so, to reinforce ideas of national identity (Frahm 2015).

While traditionally there has been a focus on borders as lines of demarcation at the outer edges of the state, there has been a more recent widening of the concept to include those bordering practices that take place elsewhere within the state's jurisdiction or, in some instances, beyond its territorial boundaries (Vallet 2016). Agreements between the EU and countries in North Africa function as devices to protect 'Fortress Europe'. Essentially, border polic- 
ing is outsourced and the border extends well into the territories of other countries at the eastern and southern edges of the EU, with bordering processes operationalized through a complex set of mechanisms and institutions (Vaughan-Williams 2008; Bialasiewicz 2012). Elsewhere we can view airports and ferry ports as sites in which bordering practices occur through the checking of passports and related travel documentation. Similarly, a variety of actors become effective border agents as these practices spatially diffuse through the state. These include employers checking the passports of employees, or haulage companies and airlines facing penalties for transporting migrants deemed to be 'illegal'. Indeed, ordinary citizens are co-opted into bordering processes by exhortations to be vigilant and to report unusual behaviour, giving rise to risks of racialized othering. Citizen surveillance serves to extend the idea of the border into almost every facet of everyday life (Vaughan-Williams 2008). In these ways, borders are not just visible dividers; they are also invisible, transitory and mobile. A wider focus on borderscapes is advocated, one that acknowledges the inherent materiality of borders but which, amongst other things, also draws attention to the experiential and the symbolic (Brambilla 2015).

In 2013 the British Home Office conducted a campaign in which advertising vans with slogans recommending that illegal immigrants should 'go home or face arrest' were dispatched to areas of Greater London with high immigrant populations. These appear to have been aimed at heightening a climate of fear through which 'illegal' migrants would be persuaded that it was in their interests to leave the country. This linked into a broader 'hostile environment' in which migrant 'others' were deliberately targeted and made to feel unwelcome and unwanted. Recent debates over immigration into the UK and other Western European countries, fuelled by populist right-wing politicians abetted by sections of the media, have tended to focus on supposed 'swarms' of asylum seekers and 'illegals', and 'hordes' of Eastern Europeans (Gilmartin 2008; Storey 2013; Maggs 2019). While this rhetoric is inaccurate and misleading, the nature of the discourse suggests that countries should increasingly seal themselves off from invasions from 'outside' by those who do not 'belong' there. These arguments are often (misleadingly) bound into security discourses, alongside cultural ones, emphasizing the importance of the border as a device to protect the integrity of the country and its citizens (Pap and Reményi 2017). Territory, terrorism and identity become inextricably entangled in debates calling into question who has the right to be in certain places and who has not.

As Jones (2016) argues, borders are inherently violent constructs. Their creation usually results from violence and their maintenance periodically requires violent actions. Depending on your perspective, borders protect through 
affording security and defence, or they act as impediments to movement. For many of a strongly nationalist political orientation, control of 'our' borders has become something of a political mantra in recent years. Borders are seen as the last line of defence of 'our' territory, keeping out undesirable 'others'. Borders become discursive devices so that defending, sealing and controlling them serve as rallying cries for political groups. Even when borders appear as strict lines, they are subject to a range of forms of regulation and they are spaces across which things (including people) flow, although those flows may be somewhat variable and asymmetric. Borders are not static but are characterized by various practices and discourses and varying levels of fluidity (Dell'Agnese and Amilhat Szary 2015; Komarova and Hayward 2019). The Polish-German border regime is rather different to the Polish-Ukraine one; while the Irish border regime changed in the late 1990s with the signing of a peace agreement, but it may be about to change again due to the UK's departure from the EU (Figure 1.3). In some cases, overt attempts are made to 'unite' border regions, such as the Greater Geneva area on the French-Swiss border, for pragmatic economic and planning imperatives so that they are presented as zones of opportunity for cooperation and convergence rather than separation and difference. This of course does not necessarily give rise to feelings of shared identity amongst border residents. Indeed, such efforts may be met with active reassertions of national identity (Sohn and Scott 2020). Elsewhere, transborder regions may operate differently. The development of so-called maquiladoras on the Mexican side of the border with the US, where factories engage in product assembly with raw material mostly shipped in and product mostly passing back out, would seem to benefit manufacturers who enjoy lower labour costs. Ultimately this mechanism depends on the very existence of the border dividing two economic spaces. The Covid-19 pandemic of 2020 resulted in the closure or partial closure of many borders, serving to reinforce ideas of territorial exclusion and giving rise to heightened fears of the 'other'.

The parcelling up of space is seldom if ever a neat exercise. Despite the apparent solidity given to territory, borders and sovereignty by maps, even the world of nation-states is riddled with indeterminate boundaries. A useful extension of thinking on the nature of territory are the various chapters in Peters et al. (2018), which focuses on spaces composed of unstable features. Important questions arise concerning ownership and control in contexts where fixed points or markers are either absent or mobile. The contributors' work focuses on the elements: earth (not always as solid as we might assume), air, water and fire. Features such as mud and ice change their form, with consequent implications for how they move, whether in solid or fluid form. Sand literally shifts underneath us and blows over, around and through political boundaries (Nieuwenhuis 2018). This transcendence of material boundaries serves 
to disrupt overly simplistic views of territory. US geopolitical interest in the Greenland icesheet and other islands of ice, as well as sub-oceanic spaces, raises questions both of territory as sub-terrain and territory in shifting forms (Bruun 2020; Squire and Dodds 2020). Offshore oil drilling requires the territorialization of chunks of ocean, while airspace is parcelled up to create corridors through which aeroplanes pass. Similar issues emerge with regard to shipping lanes, and indeed questions of sovereignty emerge in relation to the space that is an individual aeroplane or ship transiting through international waters (Lin 2018). Similar questions are posed by space missions; and these various examples focus attention, not just on surface markers, but extend our thinking of territory and borders to embrace issues of height and depth, while highlighting underlying asymmetries of power. These varied examples link into Agamben's (2005) wider idea of spaces of exception, where 'normal' rules are suspended and specific measures are seen to apply. A pertinent example relates to bodies of water (often not given adequate attention), which often assume significance in bordering practices. This is exemplified by Italian government tactics of intercepting and 'returning' migrant boats in the Mediterranean in recent years, and Greece similarly endeavouring to prevent boats containing migrants from entering its territorial waters.

\section{Territory, place and nation}

Territories, and the ways in which they are imagined, play an important role in the formation of people's self-identity and contribute to feelings of belonging or exclusion. For Maier (2016), territory can be seen as both a decision space and an identity space, so that the political and cultural are intrinsically linked. A particular mode of political organization is linked closely to ideas of belonging so that the emergence of territory has 'established possession and validated allegiances' (ibid., p. 269). People come to identify with territory and it has become central in many nationalist discourses, being habitually invoked in national conflicts where both generic territory and specific places may acquire enormous symbolism. At its most basic level is the idea of the national soil, so that fighting for, or even dying for, the land is often seen as a supreme act of patriotism in times of national conflict. In the late 19th and early 20th century, notions of blood sacrifice in pursuit of national ideals were reflected in calls to defend the land (or national soil) and fight for it. In the struggle for Irish independence in the early 20th century, rebel leader Pádraig Pearse once wrote of the need for the earth to be warmed by the blood of the battlefields. In a different context, formulations of 'blut und boden' (blood and soil) formed part of 
Nazi ideology, reflecting an explicit link between territory and ethnicity. In the 1990s, land and territory were central in the Balkans conflict characterized by attempts to purify portions of land of those seen as 'other' (Toal and Dahlman 2011). While it is easy to portray such events as irrational, for some people in specific contexts strong attachments to territory may appear to make perfect sense. In colonial (and former colonial) societies, for example, where land has been appropriated, a strong sense of ownership and defence may persist through succeeding generations, so that a collective memory of struggle for land ownership serves as a potent motivating force reflecting a material, and not simply sentimental, underpinning to an attachment to the land (Crowley 2006). The struggle for independence itself becomes a unifying thread in efforts to build a sense of nationhood so that the territory assumes its own significance, particularly in states with considerable ethnic diversity (Frahm 2015).

While history (actual or 'invented') is central to the nation's being, its right to exist usually rests on claims to a particular national space and, within this, particular places and landscapes often assume symbolic importance. There are numerous references to the 'generic' territory of the nation and allusions to the national soil even in what may appear quite banal ways (Billig 1995). Beyond the idea of the soil, particular parts of the national territory often acquire a significance as the presumed 'zone of origin' of the nation, its original heartland which remains the 'core' of the national imagination. These are often more remote and intrinsically rural places, such as wilder more remote landscapes of northern Canada, the Scottish Highlands or the west of Ireland. The supposed 'taming' of the American West means that not just the 'pioneers' heading westwards, but also the landscapes through which they travelled and the land they 'conquered', assumed significance in the nation-building project. In some Welsh nationalist discourses the mountains are seen as the heart of the nation, symbolizing a Wales untainted by outside influences. More remote and less Anglicized areas were seen to be the heartland of the nation. This is reflected in the Welsh nationalist party, Plaid Cymru, choosing an idealized representation of mountains as the original symbol of the party at its foundation in the 1920s, the physical landscape embodying the nation (Gruffud 1995). Secessionist nationalist conflicts are regularly underpinned by claims to particular places seen as integral to specific ethnic identities; claims often underpinned through reference to historical myths (White 2000; Storey 2002; Kolstø 2005). For example, Kosovo is seen as integral to Serb identity and its self-declared independence is a rupture of Serbian territorial integrity.

It is clear that land and territory are utilized in conjunction with selective interpretations of history in forging and reproducing a sense of national identity. 
When seen through a somewhat inward-looking perspective, these ideas translate as 'our' land, and this is reflected through strands of the UK referendum on leaving the EU and made apparent through some of the slogans used in that campaign, such as 'we want our country back' (Storey 2017), premised on a simplistic notion of a homogenous sense of affinity to a geographical space. This sits alongside debates over material issues, so that in the employment arena calls are made to prioritize jobs for nationals over migrant 'others' (Ince et al. 2015). In this somewhat xenophobic version of national identity, 'our' jobs are located in 'our' land and should be for 'our' people; the material, the symbolic and the geographic are intrinsically bound together so that ideas of 'us' are linked explicitly to the land and become effective mobilizing devices.

Once again, the role of mapping in inculcating a sense of territorial identification needs to be emphasized here. The map of Turkey is a commonly reproduced logo and acts as a banal signifier of the nation (Batuman 2010), serving to ingrain the territory in the popular consciousness. Jim MacLaughlin (2001) writes about his father going to school in 1920s Ireland where an outline of the island of Ireland was nailed onto the schoolroom floor. Mapping appears to rationalize space and gives solidity to the state, portraying its territorial imprint, thereby indelibly linking the state to its sovereign territory and giving it a sense of reality in the minds of its citizens. In many seemingly banal ways, the idea of the imagined community (Anderson 1991) of the wider nation is linked to a delimited geographic space which is seen to be 'ours' and which may periodically need to be defended against 'others'. People's individual welfare is conflated with the fate of a political-territorial entity. Memory and memorializing are central to many narratives of the nation and may be crucial in bolstering and reaffirming senses of national identity, as Anssi Paasi explores in Chapter 4 of this book.

Of course, many people find themselves outwith the territory of their nation as a consequence of borders. For example, a significant number of Albanians live outside the Albanian state created in 1912, forming sizeable minorities in neighbouring countries. In turn this has fuelled calls for a Greater Albania that would incorporate Kosovo, together with parts of North Macedonia and Montenegro. States endeavour to preserve their legitimacy through guardianship of the national space, but nation and state are never completely coterminous. Parts of the presumed national space may lie outside the boundaries of the state, while in other cases sub-national divisions may call into question the state's internal territorial coherence. In contested political spaces, senses of national identity play out at both the macro and the micro scale, reflected in forms of entrenched division and segregation, as highlighted by Niall Cunningham in Chapter 6 of this book. Consequently, there is a need to 
explore the ways national identity is constructed, reproduced, negotiated and contested at and across various spatial scales (Herb and Kaplan 2018).

\section{Territory, space and society}

While some of the most obvious (and contested) expressions of territoriality are manifested at the level of the state, many more micro-level examples of territorial control and territorial strategies may be observed, and this is reflected in the creation and sustaining of a vast array of spatial enclaves (Sidaway 2007). Social practices associated with race, class, gender and sexuality are spatialized with boundaries constructed and contested in people's everyday lives, while territorial strategies are used to control and to resist (Storey 2012). Issues of identity frequently have a spatial expression as social fractures are given material form through spatial divisions. Territorial practices can operate so as to restrict the mobilities of certain groups on the basis of class, ethnicity or gender. While these spaces might not necessarily be regarded as territories (and may be less obvious, more vaguely defined and with less clear-cut boundaries), these more micro-scale contexts provide insights into the ways in which geographic space is politicized through attempts to achieve particular outcomes, to exert (or resist) control, and to convey quite clear meanings to those concerned (Delaney 2005). One manifestation is through the geographies of residential housing. Class divisions are reflected in patterns of residential segregation and processes of gentrification so that poorer or working-class neighbourhoods are distinguished from middle-class or more affluent areas. The emergence of gated communities is perhaps the most obvious and clearly demarcated manifestation of this wider and long-standing phenomenon (le Goix and Webster 2008). In some contexts, this is accompanied by clustering (or separation) along ethnic lines, with the emergence of ghettos and other areas with high concentrations of specific ethnic groups. Discriminatory ideologies of race combined with class divisions, often reinforced through planning policies, may contribute towards the exclusion of people from particular areas and the negative stereotyping of such places and their residents. In these areas, segments of the population, often the young, may feel particularly marginalized, giving rise to social unrest and sometimes leading to territorially based gang behaviour.

Alongside residential segregation, recreational spaces such as golf courses, wider tourist complexes or beach resorts in various parts of the world can be seen as further examples of spatial enclaving designed to enclose the relatively privileged consumers from the excluded local 'other' (Bunnell et al. 
2006). These increasingly privatized spaces of consumption have developed in tandem with other controlled arenas such as shopping malls which reflect an erosion of shared public space and its replacement with privatized, exclusionary and highly regulated environments (Staeheli and Mitchell 2006). Alongside the creation of various other economically driven territorializations such as export processing zones, a wide array of spaces of exclusion continue to emerge which might be viewed as the outcome of an inherent tendency within capitalist social relations leading towards the ever-increasing privatization of the public domain (Vasudevan et al. 2008).

Long-standing stereotypes of women as home-makers whose rightful place is in the domestic realm have given rise to a gendering of space and the use of a territorial frame to restrict women's access to a wider public domain. Such divisions are reinforced through various geographies of fear, so that women may be afraid to walk through some areas or frequent specific streets due to fear of assault. These gendered constructions also prompt broader questions about the nature and meanings attaching to 'home' and the social construction of domestic space (Blunt and Dowling 2006). Similar issues may impact on sexual minorities who may lead more spatially restricted lives due to fear of physical or verbal homophobic abuse. At a yet more micro level, territorial behaviour occurs in all sorts of different settings including the workplace, the office or the school playground (Thomson 2005). For example, the demarcation of particular rooms within a house is also a form of territorial behaviour through which power (to include or to exclude) is expressed. Parental power is often communicated territorially through, for example, discouraging children entering some rooms in the house such as the kitchen or the parents' bedroom. Similarly, the prohibition of employees from certain rooms or areas within their place of work is an assertion of managerial power. These territorially based constructions of difference can have profound social and spatial impacts, raising important questions about power, dominance and control.

Resistance may be enabled and solidified through senses of place identity which help to facilitate forms of action aimed at obtaining particular outcomes. The formation of community or residence groups may reflect feelings of belonging or attachment to a particular place and this territorial affinity may play a mobilizing role. Territorially transgressive acts, whether protest marches or the painting of graffiti, can be employed to reclaim space and to assert basic rights and identities. Responses to homophobia may be reflected spatially through the emergence of spaces where gay people may feel more at ease through being accepted rather than rejected, scorned or ignored (or worse) by their neighbours (Browne and Ferreira 2016). Just as dominant ideologies can be reinforced through territorial practices, they can also be resisted. Territorial 
strategies are useful mechanisms in the assertion of identity, and spatial concentrations within particular geographic areas make visible people and issues that might otherwise remain unseen. They can be used to draw attention to exclusionary practices and to assert the right to be equal citizens, issues explored in more depth by Richard Yarwood in Chapter 8 of this book. Recent research has also drawn attention to territorial interactions between humans and non-humans. For example, concerns over shark attacks in shoreline areas led to efforts to deter sharks from specific spaces, with a focus on shark behaviour rather more than on the right of humans to 'invade' shark territory (Gibbs 2018). These various examples raise important questions of both power and legal jurisdiction. Chapter 9 in this book by David Storey draws attention to some more micro-geographies of territory and territoriality, while Sian Evans in Chapter 10 focuses on the more intimate connections between territory and the body.

\section{Summary}

Territories are political geographic entities that have emerged out of particular ways of conceiving geographic space. The most obvious version of this is the territorial state. Territory often constitutes a major component in shaping our everyday lives and in contributing to our senses of place, identity and belonging. Particular ideologies and social practices are manifested spatially and are reflected in struggles and territorial claims over the use and control of space. Territorial strategies are utilized in conflicts concerned with social power and identity at a range of spatial scales from the global down to the very local. These strategies may be to do with maintaining power or with resisting the imposition of power by others. States and their borders serve as exclusionary devices as well as a means through which people are classified as 'native' or 'alien'. While exclusionary ideologies may be consolidated and reinforced through territorial practices, they can also be resisted through similar means. Territoriality is a mechanism of power, and territorial formation, control, resistance and transgression are all political phenomena. Notwithstanding the evolution of a more globally interconnected world, current developments suggest a further hardening of borders and a retreat into more exclusionary forms of territorial affinity as territory continues to retain both an allure in terms of identity as well as a strategic value (Murphy 2013). Ongoing advances in security and surveillance technologies raise important questions about the ever-widening array of bordering practices engaged in by both state and non-state actors. Further research into all aspects of territorial construction, 
behaviour and thinking is needed to further unpick its many facets. The ways in which territorial thinking underlies and is woven into much political discourse and practice deserves further scrutiny. Research on territory also closely impinges into other perhaps unexpected domains, as with Stuart Elden's (2018) exploration of ideas of territory as revealed through a close reading of Shakespearean plays. The remaining chapters in this volume extend and deepen our thinking on various facets of territory and territoriality.

\section{References}

Agamben, G. (2005), State of Exception, Chicago, IL, USA and London, UK: University of Chicago Press.

Agnew, J.A. (1994), 'The territorial trap: the geographical assumptions of international relations theory', Review of International Political Economy, 1 (1), 53-80.

Agnew, J.A. (2009), Globalization and Sovereignty, Lanham, MD, USA and Plymouth, UK: Rowman \& Littlefield.

Anderson, B. (1991), Imagined Communities, London: Verso.

Ardrey, R. (1967), The Territorial Imperative: A Personal Inquiry into the Animal Origins of Property and Nations, London: Collins.

Bagaeen, S. and O. Uduku (eds) (2010), Gated Communities: Social Sustainability and Historical Gated Developments, London: Earthscan.

Bakke, K., A.M. Linke, J. O'Loughlin and G. Toal (2018), 'Dynamics of state-building after war: external-internal relations in Eurasian de facto states', Political Geography, 63, 159-173.

Bassin, M. (1987), 'Imperialism and the nation state in Friedrich Ratzel's political geography', Progress in Human Geography, 11 (4), 473-495.

Batuman, B. (2010), 'The shape of the nation: visual production of nationalism through maps in Turkey', Political Geography, 29 (4), 220-234.

Bialasiewicz, L. (2012), 'Off-shoring and out-sourcing the borders of Europe: Libya and EU border work in the Mediterranean', Geopolitics, 17, 843-866.

Billig, M. (1995), Banal Nationalism, London: SAGE.

Blakkisrud, H. and P. Kolstø (2011), 'From secessionist conflict toward a functioning state: processes of state- and nation-building in Transnistria', Post-Soviet Affairs, 27 (2), 178-210.

Blomley, N. (2016), 'The territory of property', Progress in Human Geography, 40 (5), 593-609.

Blunt, A. and R. Dowling (2006), Home, London: Routledge.

Brambilla, C. (2015), 'Exploring the critical potential of the borderscapes concept', Geopolitics 20 (1), 14-34.

Brenner, N. and S. Elden (2009), 'Henri Lefebvre on state, space, territory', International Political Sociology, 3 (4), 353-377.

Browne, K. and E. Ferreira (eds) (2016), Lesbian Geographies: Gender, Place and Power, London: Routledge.

Bruun, J.M. (2020), 'Invading the whiteness: science, (sub)terrain, and US militarisation of the Greenland ice sheet', Geopolitics, 25 (1), 167-188. 
Bunnell, T., H. Muzaini and J.D. Sidaway (2006), 'Global city frontiers: Singapore's hinterland and the contested socio-political geographies of Bintan, Indonesia', International Journal of Urban and Regional Research, 30 (1), 3-22.

Carmody, P. (2016), The New Scramble for Africa, 2nd edition, Cambridge: Polity.

Crowley, E. (2006), Land Matters: Power Struggles in Rural Ireland, Dublin: Lilliput Press.

Delaney, D. (2005), Territory: A Short Introduction, Malden, MA: Blackwell.

Delaney, D. (2009), 'Territory and territoriality', in R. Kitchin and N. Thrift (eds), International Encyclopedia of Human Geography, Volume 11, Oxford: Elsevier, pp. 196-208.

Dell'Agnese, E. and A.-L. Amilhat Szary (2015), 'Borderscapes: from border landscapes to border aesthetics', Geopolitics, 20 (1), 4-13.

Elden, S. (2009), Terror and Territory. The Spatial Extent of Sovereignty, Minneapolis, MN: University of Minnesota Press.

Elden, S. (2010), 'Land, terrain, territory', Progress in Human Geography, 34 (6), 799-817.

Elden, S. (2013a), The Birth of Territory, Chicago, IL: University of Chicago Press.

Elden, S. (2013b), 'How should we do the history of territory?', Territory, Politics, Governance, 1 (1), 5-20.

Elden, S. (2018), Shakespearean Territories, Chicago, IL: University of Chicago Press.

Fall, J.J. (2010), 'Artificial states? On the enduring geographical myth of natural borders', Political Geography, 29 (3), 140-156.

Frahm, O. (2015), 'Making borders and identities in South Sudan', Journal of Contemporary African Studies, 33 (2), 251-267.

Gibbs, L. (2018), 'Shores: sharks, nets and more-than-human territory in eastern Australia', in K. Peters, P. Steinberg and E. Stratford (eds), Terra Beyond Territory, London, UK and New York, USA: Rowman \& Littlefield, pp. 203-219.

Gilmartin, M. (2008), 'Migration, identity and belonging', Geography Compass, 2 (6), $1837-1852$.

Gottman, J. (1973), The Significance of Territory, Charlottesville, VA: University Press of Virginia.

Gruffud, P. (1995), 'Remaking Wales: nation-building and the geographical imagination, 1925-1950', Political Geography, 14 (3), 219-239.

Harley, J.B. (1988), 'Maps, knowledge and power', in D. Cosgrove and S. Daniels (eds), The Iconography of Landscape, Cambridge: Cambridge University Press, pp. 277-312.

Herb, G.H. and D.H. Kaplan (eds) (2018), Scaling Identities: Nationalism and Territoriality, Lanham, MD: Rowman \& Littlefield.

Hewitt, R. (2010), Map of a Nation: A Biography of the Ordnance Survey, London: Granta.

Ince, A., D. Featherstone, A. Cumbers, D. MacKinnon and K. Strauss (2015), 'British jobs for British workers? Negotiating work, nation, and globalization through the Lindsay oil refinery disputes', Antipode, 47 (1), 139-157.

Jones, R. (2016), Violent Borders: Refugees and the Right to Move, London: Verso.

Kadercan, B. (2015), 'Triangulating territory: a case for pragmatic interaction between political science, political geography, and critical IR', International Theory, 7 (1), $125-161$.

Kolstø, P. (ed.) (2005), Myths and Boundaries in South-Eastern Europe, London: Hurst \& Company. 
Komarova, M. and K. Hayward (2019), 'The Irish border as a European Union frontier: the implications for managing mobility and conflict', Geopolitics, 24 (3), 541-564.

Le Goix, R. and C.J. Webster (2008), 'Gated communities', Geography Compass, 2 (4), 1189-1214.

Leary, P. (2016), Unapproved Routes: Histories of the Irish Border, 1922-1972, Oxford: Oxford University Press.

Lin, W. (2018), 'Air. Spacing the atmosphere: the politics of territorialising air', in K. Peters, P. Steinberg and E. Stratford (eds), Terra Beyond Territory, London, UK and New York, USA: Rowman \& Littlefield, pp. 35-49.

MacLaughlin, J. (2001), Reimagining the Nation-state: The Contested Terrains of Nation-building, London: Pluto.

Maggs, J. (2019), 'The "Channel crossings" and the borders of Britain', Race and Class, 61 (3), 78-86.

Maier, C.S. (2016), Once Within Borders: Territories of Power, Wealth, and Belonging since 1500, Cambridge, MA, USA and London, UK: Belknap Press.

McConnell, F. (2010), 'The fallacy and the promise of the territorial trap: sovereign articulations of geopolitical anomalies', Geopolitics, 15 (4), 762-768.

Megoran, N. (2017) Nationalism in Central Asia: A Biography of the UzbekistanKyrgyzstan Boundary, Pittsburgh, PA: University of Pittsburgh Press.

Meinhof, U.H. (ed.) (2002), Living (with) Borders: Identity Discourses on East-West Borders in Europe, Aldershot: Ashgate.

Morrissey, J. (2017), The Long War: Centcom, Grand Strategy and Global Security, Athens, GA: University of Georgia Press.

Murphy, A.B. (2013), 'Territory's continuing allure', Annals of the Association of American Geographers, 103 (5), 1212-1226.

Nash, C., B. Reid and B. Graham (2016), Partitioned Lives: The Irish Borderlands, London: Routledge.

Niewenhuis, M. (2018), 'Earth. A grain of sand against a world of territory: experiences of sand and sandscapes in China', in K. Peters, P. Steinberg and E. Stratford (eds), Terra Beyond Territory, London, UK and New York, USA: Rowman \& Littlefield, pp. 19-33.

O’Loughlin, J., V. Kolossov and G. Toal (2011), 'Inside Abkhazia: survey of attitudes in a de facto state', Post-Soviet Affairs, 27 (1), 1-36.

Paasche, T.F., R. Yarwood and J.D. Sidaway (2014), 'Territorial tactics: the socio-spatial significance of private policing strategies in Cape Town', Urban Studies, 51 (8), 1559-1575.

Paasi, A. (2008), 'Territory', in J. Agnew, K. Mitchell and G. Toal (eds), A Companion to Political Geography, Malden, MA: Blackwell, pp. 109-122.

Paasi, A. (2009), 'Bounded spaces in a "borderless world": border studies, power and the anatomy of territory', Journal of Power, 2 (2), 213-234.

Paasi, A., J. Harrison and M. Jones (eds) (2018), Handbook on the Geographies of Regions and Territories, Cheltenham, UK and Northampton, MA, USA: Edward Elgar Publishing.

Painter, J. (2010), 'Rethinking territory', Antipode, 42 (5), 1098-1118.

Pap, N. and P. Reményi (2017), 'Re-bordering of the Hungarian South: geopolitics of the Hungarian border fence', Hungarian Geographical Bulletin, 66 (3), 235-250.

Peters, K., P. Steinberg and E. Stratford (eds) (2018), Terra Beyond Territory, London, UK and New York, USA: Rowman \& Littlefield.

Raffestin, C. (2012), 'Space, territory and territoriality', Environment and Planning D: Society and Space, 30 (1), 121-141. 
Sack, R. (1986), Human Territoriality: Its Theory and History, Cambridge: Cambridge University Press.

Sandars, C.T. (2000), America's Overseas Garrisons: The Leasehold Empire, Oxford: Oxford University Press.

Sassen, S. (2013), 'When territory deborders territoriality', Territory, Politics, Governance, 1 (1), 21-45.

Sidaway, J.D. (2007), 'Enclave space: a new metageography of development?' Area, 39 (3), 331-339.

Smyth, W.J. (2006), Map-making, Landscapes and Memory: A Geography of Colonial and Early Modern Ireland c. 1530-1750, Cork: Cork University Press.

Sohn, C. and J.W. Scott (2020), 'Ghost in the Genevan borderscape! On the symbolic significance of an "invisible" border', Transactions of the Institute of British Geographers, 45 (1), 18-32.

Squire, R. and K. Dodds (2020), 'Introduction to the special issue: subterranean geopolitics', Geopolitics, 25 (1), 4-16.

Staeheli, L.A. and D. Mitchell (2006), 'USA's destiny? Regulating space and creating community in American shopping malls', Urban Studies, 43 (5-6), 977-992.

Storey, D. (2002), 'Territory and national identity: examples from the former Yugoslavia', Geography, 87 (2), 108-115.

Storey, D. (2012), Territories: The Claiming of Space, 2nd edition, London: Routledge.

Storey, D. (2013), “New” migrants in the British countryside', Journal of Rural and Community Development, 8 (3), 291-302.

Storey, D. (2017), 'States, territory and sovereignty', Geography, 10 (3), 116-122.

Terlouw, K. (2018), 'Regional identities: quested and questioned', in A. Paasi, J. Harrison and M. Jones (eds), Handbook on the Geographies of Regions and Territories, Cheltenham, UK and Northampton, MA, USA: Edward Elgar Publishing, pp. 256-267.

Thomson, S. (2005), “Territorialising” the primary school playground: deconstructing the geography of playtime', Children's Geographies, 3 (1), 63-78.

Toal, G. and C.T. Dahlman (2011), Bosnia Remade: Ethnic Cleansing and its Reversal, Oxford, UK and New York, USA: Oxford University Press.

Vallet, E. (2016), Borders, Fences and Walls: State of Insecurity?, London: Routledge.

Vasudevan, A., C. McFarlane and A. Jeffrey (2008), 'Spaces of enclosure', Geoforum, 39 (5), 1641-1646.

Vaughan-Williams, N. (2008), 'Borderwork beyond inside/outside? Frontex, the citizen-detective and the war on terror', Space and Polity, 12 (1), 63-79.

White, G.W. (2000), Nationalism and Territory: Constructing Group Identity in Southeastern Europe, London: Rowman \& Littlefield. 